\title{
Oncogene CSF1R
}

National Cancer Institute

\section{Source}

National Cancer Institute. Oncogene CSF1R. NCI Thesaurus. Code C16240.

Human colony stimulating factor 1 receptor (CSF1R) gene, located at 5q33.2-q33.3,

encodes macrophage colony stimulating factor I receptor protein. Mutations in this gene have been detected in both chronic myelomonocytic leukemia and type M4 acute

myeloblastic leukemia. One out of fifty hematologically normal individuals exhibit a CSFR1 variant allele (Y969C) that may cause a predisposition to myeloid malignancy. 